\title{
Alpha2-Antiplasmin: The Devil You Don't Know in Cerebrovascular and Cardiovascular Disease
}

\author{
Satish Singh, Sofiyan Saleem and Guy L. Reed* \\ Department of Medicine, University of Arizona-College of Medicine, Phoenix, AZ, United States
}

Alpha2-antiplasmin ( $\alpha 2 A P)$, the fast-reacting, serine protease inhibitor (serpin) of plasmin, was originally thought to play a key role in protection against uncontrolled, plasmin-mediated proteolysis of coagulation factors and other molecules. However, studies of humans and mice with genetic deficiency of a2AP have expanded our understanding of this serpin, particularly in disease states. Epidemiology studies have shown an association between high $\alpha 2 \mathrm{AP}$ levels and increased risk or poor outcome in cardiovascular diseases. Mechanistic studies in disease models indicate that $\alpha 2 \mathrm{AP}$ stops the body's own fibrinolytic system from dissolving pathologic thrombi that cause venous thrombosis, pulmonary embolism, arterial thrombosis, and ischemic stroke. In addition, $\alpha 2$ AP fosters the development of microvascular thrombosis and enhances

OPEN ACCESS

Edited by:

Alexandra R. Lucas,

Arizona State University, United States

Reviewed by:

Margarethe Geiger,

Medical University of Vienna, Austria

Paul J. Declerck,

KU Leuven, Belgium

*Correspondence:

Guy L. Reed

guyreed@email.arizona.edu

Specialty section:

This article was submitted to

Atherosclerosis and Vascular

Medicine,

a section of the journal

Frontiers in Cardiovascular Medicine

Received: 22 September 2020 Accepted: 02 December 2020

Published: 23 December 2020

Citation:

Singh S, Saleem S and Reed GL (2020) Alpha2-Antiplasmin: The Devil You Don't Know in Cerebrovascular and Cardiovascular Disease.

Front. Cardiovasc. Med. 7:608899,

doi: 10.3389/fcvm.2020.608899 matrix metalloproteinase-9 expression. Through these mechanisms and others, a2AP contributes to brain injury, hemorrhage and swelling in experimental ischemic stroke. Recent studies also show that $\alpha 2 \mathrm{AP}$ is required for the development of stasis thrombosis by inhibiting the early activation of effective fibrinolysis. In this review, we will discuss the key role played by $\alpha 2 \mathrm{AP}$ in controlling thrombosis and fibrinolysis and, we will consider its potential value as a therapeutic target in cardiovascular diseases and ischemic stroke.

Keywords: alpha2-antiplasmin, ischemic stroke, pulmonary embolism, deep vein thrombosis, fibrinolysis, thrombosis, plasmin

\section{ALPHA2-ANTIPLASMIN ( $\alpha 2 A P)$ IS THE SERPIN THAT KILLS PLASMIN}

$\alpha 2 \mathrm{AP}$ (also known as $\alpha 2$-plasmin inhibitor, antiplasmin, serpinf2, plasmin inhibitor), is an ultrafast covalent inhibitor of plasmin (1-3) and, is a crucial member of the serine protease inhibitor (serpin) family. $\alpha 2 \mathrm{AP}$ was first described by three different investigators as the fast-acting inhibitor of plasmin (4-6), who named it differently as $\alpha 2$-plasmin inhibitor (5), antiplasmin (6) and primary plasmin inhibitor $(4,7) . \alpha 2 \mathrm{AP}$ is present in the blood at nearly half the concentration $(\sim 1 \mu \mathrm{M})$ of its target enzyme precursor, plasminogen $(\sim 2 \mu \mathrm{M})(6,8)$. Structurally, $\alpha 2 \mathrm{AP}$ is a unique serpin (Figure 1) with a 12 amino acid $\mathrm{N}$-terminus, a central serpin domain and a C-terminal tail that is $\sim 55$-residues long (10-12). Mechanistically, the C-terminal lysine residues of $\alpha 2 \mathrm{AP}$ initially bind non-covalently to the kringle domains of plasmin to form a 1:1 stoichiometric complex (13). Plasmin then cleaves the reactive center loop of $\alpha 2 \mathrm{AP}$ at $\mathrm{Arg}^{376}-\mathrm{Met}^{377}$ bond and forms an inactive, covalent complex $(1-3,14)$. However, mutations in the $\alpha 2 \mathrm{AP}$ molecule or monoclonal antibodies against $\alpha 2 \mathrm{AP}$ can change the plasmin- $\alpha 2 \mathrm{AP}$ interaction to an enzyme-substrate reaction (an alternate mechanism of serpin interaction) where active plasmin leaves the complex after cleaving $\alpha 2 \mathrm{AP}$ (15). 


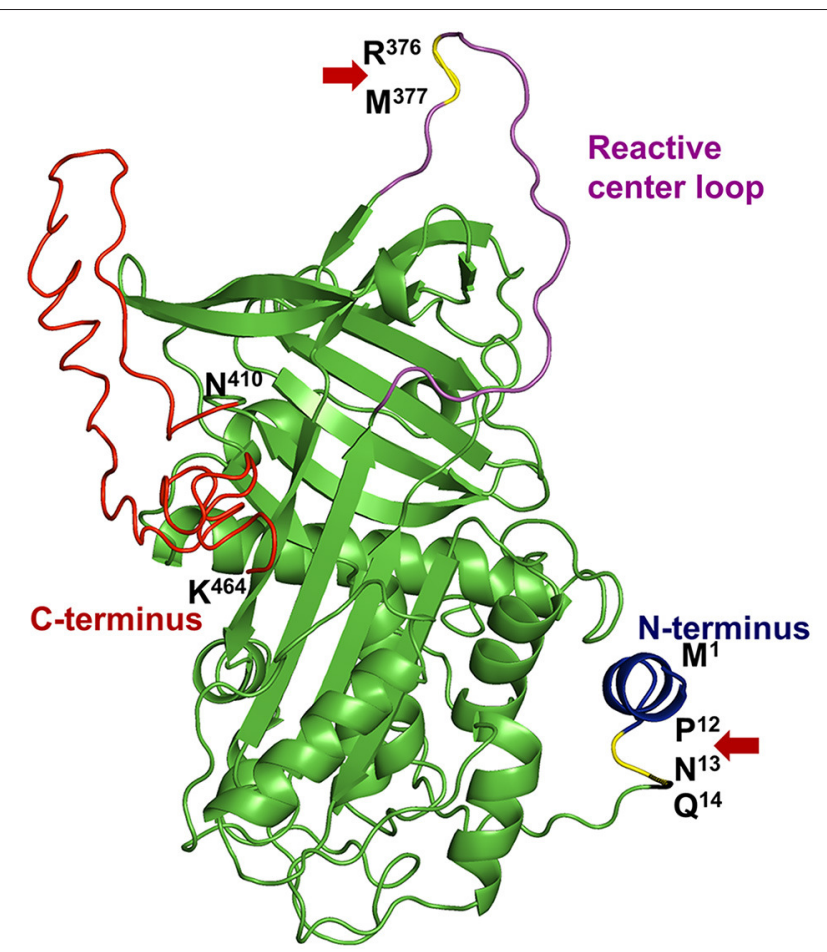

FIGURE 1 | Structural elements of $\alpha 2 A P$. The protein structure of human $\alpha 2 A P$ was generated by homology modeling using an online I-TASSER server (9) based on the crystal structure of mouse $\alpha 2 \mathrm{AP}$ (PDB: 2R9Y) (10). $\alpha 2 \mathrm{AP}$ has a central serpin domain and, $\mathrm{N}$ - \& C-terminal extensions with specific functions. The $\mathrm{N}$-terminus (blue) of $\alpha 2 \mathrm{AP}$ is cleaved in the circulation by APCE at the Pro $^{12}-A_{s n^{13}}$ site $\left(P^{12}-\mathrm{N}^{13}\right.$, yellow highlighted and Red arrow) to form $\mathrm{Asn}^{13}-\alpha 2 \mathrm{AP}$ which represents $70 \%$ of blood $\alpha 2 \mathrm{AP}$ levels. $\mathrm{Gl}^{14}\left(\mathrm{Q}^{14}\right)$ residue of $\alpha 2 A P$ is cross-linked to fibrin by transglutaminase enzyme, activated factor XIII. The reactive center loop (magenta) protrudes out from the central serpin domain (green) of $\alpha 2 A P$. Plasmin cleaves at $\mathrm{Arg}^{376}-\mathrm{Met}^{377}$ bond $\left(\mathrm{R}^{376}-\mathrm{M}^{377}\right.$, yellow highlighted, and red arrow) in the reactive center loop to form the inactive complex. A $\sim 55$ residue long C-terminus (red) (Asn ${ }^{410}$-Lys ${ }^{464}$; $\mathrm{N}^{410}-\mathrm{K}^{464}$ ) of a2AP is important for initial binding with plasmin due to the presence of multiple lysine residues.

\section{$\alpha 2 A P$ EXPRESSION}

a2AP is primarily synthesized by hepatocytes in the liver and released into the blood $(16,17)$. After synthesis, $\alpha 2 \mathrm{AP}$ is enzymatically modified in the circulation at both the $\mathrm{N}$ - and C-terminus, which affects its fibrin-crosslinking and plasmin(ogen) binding capabilities respectively (18). Lower levels of $\alpha 2 \mathrm{AP}$ are also detected in the human kidney, blood platelets, the gastrointestinal tract, muscles, lungs, placenta, and brain (cerebral cortex, hippocampus, and cerebellum) (https://www. proteinatlas.org/ENSG00000167711-SERPINF2/tissue) (19-21). a2AP is present among diverse species from mammals to birds and fish and there is significant protein sequence homology among various species such as humans, mice, bovine, etc. $(11,22-$ 26). Human and mouse $\alpha 2 \mathrm{AP}$ have similar kinetic constants for inhibition of autologous and heterologous plasmin in vitro (27). Administration of physiologic concentrations of human $\alpha 2 \mathrm{AP}$ to $\alpha 2 \mathrm{AP}$-deficient $\left(\alpha 2 \mathrm{AP}^{-/-}\right)$mice restores fibrinolytic inhibition and thrombosis to approximately normal levels (28). Since mouse and human $\alpha 2 \mathrm{AP}$ have similar properties and crossspecies reactivity, $\alpha 2 \mathrm{AP}^{-/-}$mice have provided an excellent translational model to examine the function of $\alpha 2 \mathrm{AP}$.

\section{$\alpha 2 A P$ AND CONTROL OF FIBRINOLYSIS}

a2AP is covalently cross-linked to fibrin in the thrombus by activated factor XIII, a transglutaminase (29-31) which is a major source of the resistance of in vitro plasma clots to plasminmediated fibrinolysis (32-35). Once released into plasma, $\mathrm{Met}^{1}$ $\alpha 2 \mathrm{AP}$ is clipped by $\alpha 2 \mathrm{AP}$ cleaving-enzyme (APCE) at the Nterminus to generate the truncated $\mathrm{Asn}^{13}-\alpha 2 \mathrm{AP}$ (Figure 1), which is incorporated into the fibrin network 13 times faster than uncleaved Met $^{1}-\alpha 2 \mathrm{AP}$ (36). Plasmin activity is partially protected from $\alpha 2 \mathrm{AP}$ inhibition when its lysine binding sites are engaged with fibrin in the clot (37-39) or on the surface of a cell, such as endothelial cells (40). The relative contribution of activated factor XIII-mediated fibrin-fibrin cross-linking (41) vs. fibrin- $\alpha 2 \mathrm{AP}$ crosslinking to thrombus resistance has been debated (35). Most of the studies suggest that fibrin- $\alpha 2 \mathrm{AP}$ crosslinking is the major determinant of fibrinolytic resistance of the thrombus $(34,42-44)$. Under in vivo conditions, activated factor XIII also may contribute to the dynamics of thrombosis through secondary interactions such as red blood cell retention $(45,46)$, or cross-linking of other fibrinolytic inhibitors such as plasminogen activator inhibitor-1 (PAI-1) and thrombinactivatable fibrinolysis inhibitor (TAFI). In vitro, fibrinolysis assays showed that $\alpha 2 \mathrm{AP}$ works synergistically with other major fibrinolytic inhibitors including TAFI or PAI-1 (47). In vivo, TAFI-deficient mice have variable effects in different pulmonary embolism models $(48,49)$. In contrast, $\alpha 2 \mathrm{AP}^{-/-}$mice showed greater fibrinolytic dissolution of ex vivo pulmonary thrombi as compared to PAI-1 deficient mice (50), suggesting that $\alpha 2 \mathrm{AP}$ is the dominant contributor to thrombus resistance against fibrinolysis (50).

\section{ROLE OF $\alpha 2 A P$ IN ANIMAL MODELS OF CARDIOVASCULAR AND CEREBROVASCULAR DISEASES}

\section{Role of $\alpha 2 A P$ in Ischemic Stroke}

Human ischemic stroke is primarily caused by thrombotic arterial occlusion of a middle cerebral artery which interrupts the supply of blood, oxygen and nutrients, leading to ischemia, inflammation, breakdown of the blood-brain barrier and neuronal cell death (51). Higher blood levels of $\alpha 2 \mathrm{AP}$ are associated with an increased risk of human ischemic stroke and may contribute to the failure of recombinant-tissue plasminogen activator (r-tPA) therapy for reperfusion in stroke patients $(52,53)$.

Experimental studies show that $\alpha 2 \mathrm{AP}$ regulates fibrinolysis during ischemic stroke and has deleterious effects that worsen brain injury by enhancing thrombo-inflammatory mechanisms (54). In a mouse model of thromboembolic occlusion of the middle cerebral artery, Houng et al. (55) showed that increased 
blood levels of $\alpha 2 \mathrm{AP}$ reduced thrombus dissolution after treatment with r-tPA. Increased blood levels of $\alpha 2 \mathrm{AP}$ also worsened brain infarction and brain swelling (55) (Figure 2). In contrast, $\alpha 2 \mathrm{AP}$ inactivation ( $\alpha 2 \mathrm{AP}-\mathrm{I})$ enhanced r-tPAmediated thrombus dissolution, in addition to reducing cerebral infarction, brain swelling and brain hemorrhage (55) (Figure 2). Treatment with the $\alpha 2$ AP-I led to reduced TUNEL-staining, decreased caspase-3 expression and diminished breakdown of the blood-brain barrier. Subsequent studies showed that $\alpha 2 \mathrm{AP}$ had dose-dependent deleterious effects in ischemic stroke in mice: it reduced thrombus dissolution and worsened cerebral infarction, brain swelling, and blood-brain barrier breakdown (56) (Figure 2). Increasing blood levels of $\alpha 2 \mathrm{AP}$ enhanced ischemic brain injury, in part through a matrixmetalloproteinase-9 (MMP-9)-dependent mechanism (67). In contrast, both $\alpha 2 \mathrm{AP}$ deficiency $\left(\alpha 2 \mathrm{AP}^{-/-}\right)$or $\alpha 2 \mathrm{AP}-\mathrm{I}$ reduced brain infarction, hemorrhage and brain swelling (5456). Also, $\alpha 2$ AP deficiency or $\alpha 2$ AP-I reduced microvascular thrombosis and MMP-9 expression (54, 56). Importantly, $\alpha$ AP-I significantly enhanced acute $(24 \mathrm{~h})$ and longer-term (1 week) survival by comparison to r-tPA therapy and controls (54-56). Also, a2AP-I significantly improved neurobehavioral outcomes (54-56).

The effects of $\alpha 2 \mathrm{AP}$ on ischemic stroke have also been studied in ischemic stroke, induced by mechanical arterial ligation or occlusion. Nagai et al. found that $\alpha 2 \mathrm{AP}^{-/-}$mice had reduced ischemic brain injury in comparison to control mice with normal $\alpha 2 \mathrm{AP}$ levels after permanent ligation of the middle cerebral artery (57) (Figure 2). Similarly, inhibition of $2 \mathrm{AP}$ activity by intravenous infusion of plasmin/microplasmin or a monoclonal antibody significantly reduced focal ischemic brain injury after middle cerebral artery ligation in mice and hamsters (58). In ischemic stroke caused by middle cerebral artery photothrombotic occlusion, Suzuki et al. (68) found that doses of microplasmin that were equally effective for reducing ischemic cerebral infarction to r-tPA, caused less intracerebral bleeding and reduced tail bleeding time. However, higher doses of microplasmin that fully depleted circulating $\alpha 2 \mathrm{AP}$ increased intracerebral bleeding $(68,69)$. It is interesting to note that $\alpha 2 \mathrm{AP}$ deficiency or inhibition improved stroke outcomes in stroke models caused by an occluding thrombus and by mechanical ligation, suggesting the role of $\alpha 2 \mathrm{AP}$ in stroke may extend beyond its role in thrombus dissolution.

\section{Role of $\alpha 2 \mathrm{AP}$ in Deep Vein Thrombosis}

Since its discovery, the effects of $\alpha 2 \mathrm{AP}$ were considered to be restricted to inhibiting the dissolution of formed thrombi; it was not thought to have a role in regulating thrombus formation or thrombosis (70). However, new data show that $\alpha 2 \mathrm{AP}$ regulates thrombus initiation and thrombus development, and is required for the occurrence of stasis induced deep vein thrombosis in mice (64) (Figure 2). In mice with normal levels of $\alpha 2 \mathrm{AP}$, thrombosis induces plasmin generation (64), however thrombosis proceeds because the plasmin generated, is insufficient to overcome the anti-fibrinolytic effects of $\alpha 2 \mathrm{AP}$. In contrast, in $\alpha 2 \mathrm{AP}$ deficiency, plasmin-driven fibrinolysis

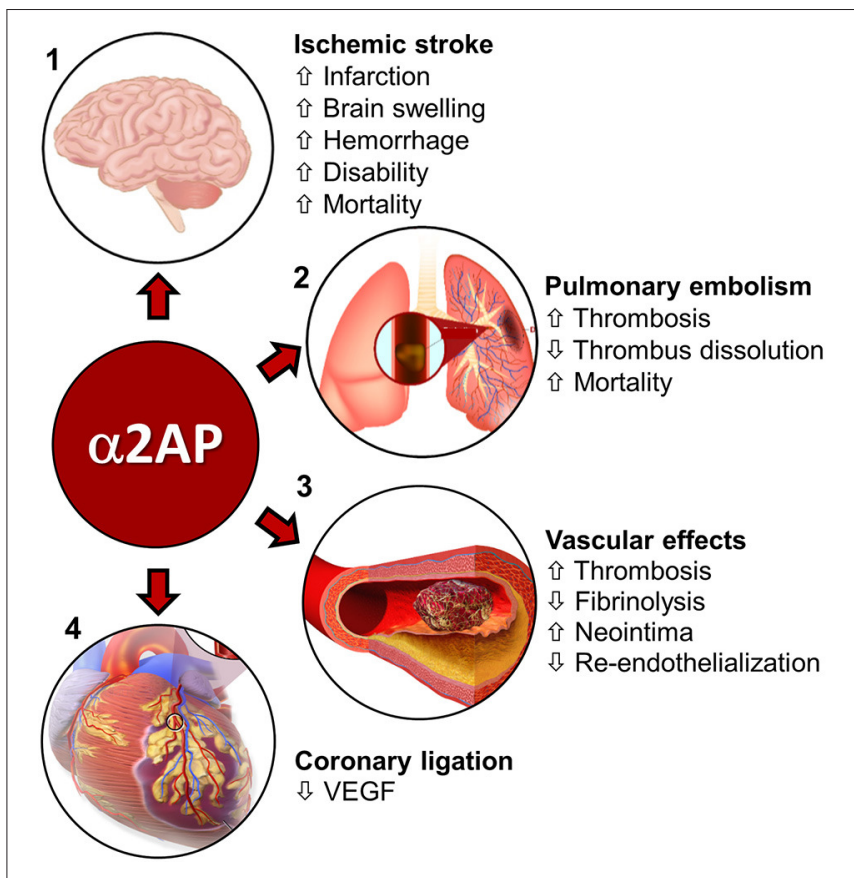

FIGURE 2 | Role of $\alpha 2 A P$ in cardiovascular diseases. (1) Ischemic stroke- $\alpha 2 A P$ increases cerebral infarction, brain swelling, hemorrhage, and, disability and mortality during ischemic stroke in mice (55-59). Image source-(https://www.injurymap.com/free-human-anatomy-illustrations). (2) Pulmonary embolism- $\alpha 2 \mathrm{AP}$ decreases thrombus dissolution and, increases thrombosis in the lungs and mortality during pulmonary embolism in mice (28, 60-62). Image source-(http://apsfa.org/pulmonary-embolism/). (http:// www.nhlbi.nih.gov/health/dci/Diseases/pe/pe_what.html). (3) In arterial (carotid artery injury) and venous (IVC, jugular vein) injury/thrombosis models, $\alpha 2 A P$ increases thrombosis and decreases fibrinolysis $(63,64) . \alpha 2 A P$ is also associated with increased neointima formation and reduced endothelialization over time (65). Image source-(https://commons.wikimedia.org/wiki/File: Blausen_0088_BloodClot.png). (4) Coronary artery ligation- $\alpha 2$ AP decreases VEGF levels in mice, which affect pulmonary vascular permeability (66). Image source-modified from (https://commons.wikimedia.org/wiki/File:Blausen_ 0463_HeartAttack.png).

prevents the initiation and establishment of thrombosis. Indeed, in venous thrombosis induced by stasis (no blood flow), or by stenosis (reduced flow), $\alpha 2 \mathrm{AP}^{-/-}$mice do not develop thrombosis even after hours to weeks (64). The requirement for $\alpha 2 \mathrm{AP}$ to enable the development of thrombosis appears to be mediated through its inhibition of plasmin because another plasmin inhibitor, $\varepsilon$-aminocaproic acid (64) will restore thrombus formation in the absence of $\alpha 2 \mathrm{AP}$. How $\alpha 2 \mathrm{AP}$ affects other key components of venous thrombosis such as neutrophils, monocytes or coagulation system components needs further investigation.

In a jugular vein thrombosis model (endothelial injury) in mice, $\alpha 2 \mathrm{AP}$ deficiency caused delayed occlusion and early reperfusion in comparison to wild type controls (Figure 2) (63). An $\alpha 2$ AP-I alone or in combination with r-tPA increased the dissolution of human plasma thrombi in a jugular vein thrombosis model in rabbits (71). The combination of r-tPA with the $\alpha 2 \mathrm{AP}$ antibody did not increase fibrinogen degradation (71) 
suggesting that $\alpha 2 \mathrm{AP}-\mathrm{I}$ may enhance the specificity of fibrinolysis by plasminogen activators.

\section{$\alpha 2 A P$ in Pulmonary Embolism}

Pulmonary embolism is caused when the thrombi formed in the deep veins of the legs or other sites detach from the vascular wall and travel to the lungs to cause serious, lifethreatening complications (72). Therapy with r-tPA is limited to high-risk pulmonary embolism patients because clinical trials have shown r-tPA can cause serious or fatal bleeding (72). In vivo studies in mice and other animals have shown that thrombus dissolution can be achieved by $\alpha 2$ AP-I with increased efficacy without increased bleeding. In a pulmonary embolism model in ferrets, $\alpha 2$ AP-I by a monoclonal antibody increased experimental thrombus dissolution by r-tPA without increased fibrinogen degradation (60). Similarly, $\alpha 2 \mathrm{AP}^{-/-}$mice showed enhanced dissolution of pulmonary emboli made from $\alpha 2 \mathrm{AP}^{+/+}$or $\alpha 2 \mathrm{AP}^{-/-}$mouse plasma (61) (Figure 2), but in two different bleeding tests, $\alpha 2 \mathrm{AP}^{-/-}$mice did not show enhanced bleeding when compared to $\alpha 2 \mathrm{AP}^{+/+}$mice (61). Other hemostatic parameters including plasminogen, PAI-1 levels, hematocrit and fibrinogen levels were comparable in $\alpha 2 \mathrm{AP}^{-/-}$and $\alpha 2 \mathrm{AP}^{+/+}$mice (61). The role of $\alpha 2 \mathrm{AP}$ was also studied in a pulmonary thrombosis model induced by photochemical irradiation of Rose Bengal in the jugular vein in $\alpha 2 \mathrm{AP}^{-/-}$mice (73) (Figure 2). In this model, $\alpha 2 \mathrm{AP}$ deficiency was associated with decreased deposition of endogenous fibrin in pulmonary vessels and increased survival in comparison to wild type controls $\left(\alpha 2 \mathrm{AP}^{+/+}\right)$(73). There were no differences in the bleeding time in $\alpha 2 \mathrm{AP}^{-/-}$mice treated by r-tPA (73). Inhibition of the crosslinking of $\alpha 2 \mathrm{AP}$ to fibrin by activated factor XIII markedly enhanced fibrinolysis in experimental pulmonary thromboembolism (44). Finally, the comparative effects of an a2AP-I and r-tPA were examined in a humanized model of pulmonary embolism in mice. The $\alpha 2 \mathrm{AP}-\mathrm{I}$ alone showed comparable efficacy to high dose r-tPA in thrombus dissolution (28) (Figure 2). Treatment with r-tPA increased fibrinogen consumption and prolonged bleeding times but $\alpha 2 \mathrm{AP}-\mathrm{I}$ did not cause these effects. Combination treatment with very low dose $r-$ tPA and $\alpha 2$ AP-I was more effective at dissolving thrombi than a much higher dose of r-tPA alone, but the combination did not cause increased fibrinogen degradation and/or prolonged bleeding time (28) (Figure 2).

\section{a2AP in Arterial Injury and Thrombosis}

The role of $\alpha 2 \mathrm{AP}$ in arterial thrombosis was investigated by Matsuno et al. (63) by inducing endothelial injury of the murine carotid artery (Figure 2). $\alpha 2 \mathrm{AP}$ deficiency did not change the time for thrombotic occlusion of the carotid artery but it significantly accelerated spontaneous reperfusion indicating that $\alpha 2 \mathrm{AP}$ played a major role in arterial fibrinolysis (63). In studies of femoral arterial injury induced by electric current, $\alpha 2 \mathrm{AP}$ did not appear to affect smooth muscle cell migration and neointima formation 2-3 weeks after injury (74). However, in carotid artery injury induced by Rose Bengal photo-irradiation, there was increased re-endothelialization and reduced neointima formation in $\alpha 2 \mathrm{AP}^{-/-}$mice in comparison with $\alpha 2 \mathrm{AP}^{+/+}$mice (65) (Figure 2). The increased re-endothelialization was attributed to the increased plasmin-mediated generation of vascular endothelial growth factor in $\alpha 2 \mathrm{AP}^{-/-}$mice (Figure 2). Finally, Ang II and N(omega)-nitro-L-arginine methyl ester (L-NAME)-induced vascular remodeling (perivascular fibrosis) was significantly decreased in $\alpha 2 \mathrm{AP}^{-/-}$mice compared with wild-type mice (75).

\section{$\alpha 2 \mathrm{AP}$ in Coronary Artery Ligation}

Coronary thrombosis is the primary cause of human myocardial infarction (76) but a reproducible model of coronary thrombosis has not been established in mice (77), which limits the translational relevance of experimental studies. Nevertheless, in a left coronary artery permanent ligation model in mice, $\alpha 2 \mathrm{AP}$ deficiency was associated with increased plasmin-mediated vascular endothelial growth factor release, which enhanced pulmonary vascular permeability (Figure 2). Unfortunately, the effects of $\alpha 2 \mathrm{AP}$ deficiency on thrombosis or fibrinolysis could not be assessed in this model. The role of $\alpha 2 \mathrm{AP}$ in an ischemia-reperfusion model of myocardial infarction has not been studied.

\section{a2AP in Thrombotic Thrombocytopenic Purpura}

Thrombotic thrombocytopenic purpura (TTP) is a rare but severe thrombotic disorder causing microvascular thrombosis in various organs and low platelet counts (78). In ADAMTS deficiency-induced experimental TTP in mice, there are increased levels of von Willebrand factor in the blood and microthrombi. However, increased plasmin activity by $\alpha 2 \mathrm{AP}$ deficiency in mice causes increased proteolysis of von Willebrand factor and resolves the signs of disease (79).

\section{NON-FIBRINOLYTIC EFFECTS OF $\alpha 2 A P$}

a2AP may have non-fibrinolytic effects under different pathophysiological conditions. $\alpha 2 \mathrm{AP}$ deficiency in mice decreases fibrosis in different models of fibrotic diseases $(80,81)$. Cancer is one of the major risk factors for deep vein thrombosis and $\alpha 2 \mathrm{AP}$ enables deep vein thrombosis (64); however, it also restricts lymphatic remodeling and metastasis in a mouse model of cancer (82). In the brain, $\alpha 2 \mathrm{AP}$ is expressed mainly by hippocampal neurons and is required for dendrite growth through p38 microtubule-associated protein kinase pathways in mice $(83,84)$. $\alpha 2 \mathrm{AP}$ deficiency has been associated with impairment in motor function, cognitive function, anxiety, and depression-like behavior in mice (85). In a mouse model of Alzheimer's disease, chronic depletion of blood $\alpha 2 \mathrm{AP}$ by antisense oligonucleotide treatment increased the activation of macrophage/microglial cells and increased fibrillar plaque, though it did not alter total plaque deposition (86). $\alpha 2 \mathrm{AP}$ deficiency accelerates wound healing, perhaps through an increase in the release of vascular endothelial growth factor (87). Inhibitors of mouse $\alpha 2 \mathrm{AP}$ increase liver repair after injury when compared to controls (88). $\alpha 2 \mathrm{AP}$ deficiency also decreases arteriosclerosis after vascular injury (65). 


\section{DEFICIENCY OF $\alpha 2 A P$ IN HUMANS-CONGENITAL AND ACQUIRED}

Congenital deficiency of $\alpha 2 \mathrm{AP}$ (Miyasato disease) in humans is very rare and has been associated with a phenotype of delayed traumatic or spontaneous rebleeding, usually in the form of hematomas or hemarthroses (89-91). Spontaneous cerebral bleeding has not been reported as an issue in humans (89-91). Bleeding in $\alpha 2 \mathrm{AP}$ deficiency is usually controlled by standard measures or with tranexamic acid or $\varepsilon$-aminocaproic acid, which block plasmin-mediated fibrinolysis (91). Indeed, $\alpha 2$ AP-deficient patients have successfully undergone heart surgery with these agents. Homozygous genetic deficiency has been described in a 62-year-old patient (92), indicating that the life-long absence of $\alpha 2 \mathrm{AP}$ can be tolerated. Heterozygous individuals normally do not show bleeding phenotype unless there is a trauma or surgery; and sporadic reports of $\alpha 2 \mathrm{AP}$ heterozygous deficiency in patients as old as 83 years are reported (93).

Congenital deficiency can be either quantitative with reduced protein levels or qualitative with reduced protein function but both are difficult to detect as routine coagulation tests and other hemostatic parameters are normal in patients. Quantitative deficiency of $\alpha 2 \mathrm{AP}$ with reduced protein levels may be caused by a point mutation ( $\alpha 2 \mathrm{AP}$-Paris Trousseau, 15\% levels, and $\alpha 2 \mathrm{AP}$ $\mathrm{Val}^{384}$-Met, $\sim 50 \%$ levels), or a deletion ( $\alpha 2 \mathrm{AP}-$ Okinawa, $<1 \%$ ) or a frameshift mutation ( $\alpha 2 \mathrm{AP}-\mathrm{Nara},<1 \%$ level) (91). A qualitative or functional deficiency of human $\alpha 2 \mathrm{AP}$ (Enschede) is due to an insertional mutation in the reactive center loop of $\alpha 2 \mathrm{AP}$ (an additional alanine), which causes it to behave like a substrate of plasmin instead of an inhibitor $(94,95)$.

Acquired deficiency of $\alpha 2 \mathrm{AP}$ may be caused by thrombolytic agents (e.g., plasminogen activators, plasmin, and microplasmin) or disease conditions such as severe liver disease and acute leukemia (54). Increased levels of $\alpha 2 \mathrm{AP}$ are associated prospectively with an elevated risk of myocardial infarction (96) and ischemic stroke (52). In Alzheimer's disease patients, $\alpha 2 \mathrm{AP}$ expression increases in the brain tissue and is associated with amyloid $\beta$ plaques (20). During early studies of plasminogen activators, levels of $\alpha 2 \mathrm{AP}$ were noted to fall before or synchronously with fibrinogen levels, which was a harbinger of clinical bleeding complications (97, 98). Indeed, $\alpha 2 \mathrm{AP}$ supplementation was considered as an adjuvant to r-tPA therapy to prevent bleeding complications (99). However, more recent studies show that $\alpha 2 \mathrm{AP}$ is the dominant inhibitor of physiologic fibrinolysis and that elevated levels of $\alpha 2 \mathrm{AP}$ may be harmful in cardiovascular and cerebrovascular diseases $(1,26)$.

\section{THERAPEUTIC STRATEGIES TARGETING $\alpha 2 A P$}

Thrombosis is the leading cause of cardiovascular and cerebrovascular deaths (100). There have been two primary strategies for treating thrombotic diseases: anticoagulation to prevent thrombus formation or expansion, and fibrinolytics to dissolve existing thrombi. Anticoagulation therapy is widely used to prevent thrombosis in patients with myocardial infarction, ischemic stroke, deep vein thrombosis and pulmonary embolism $(51,72,101)$. The value of anticoagulation is limited by bleeding and by the fact that it does not dissolve existing thrombi. Fibrinolytic (thrombolytic) therapy triggers the dissolution of existing thrombi. Plasminogen activators such as $\mathrm{r}$-tPA, tenecteplase, and streptokinase are the most widely used fibrinolytic agents. The value of plasminogen activator therapy is limited by bleeding and other toxicities, which restrict therapy to a small subset of those who might benefit from thrombus dissolution for treatment of ischemic stroke, myocardial infarction, pulmonary embolism, etc. $(51,72)$ Experimental studies suggest that targeting $\alpha 2 \mathrm{AP}$ is a novel paradigm for preventing thrombosis and dissolution of thrombi without compromising safety. Several strategies have been described including specific monoclonal antibodies, peptides, and microplasmin to neutralize the activity of $\alpha 2 \mathrm{AP}$.

\section{Monoclonal Antibodies Inhibiting $\alpha 2 \mathrm{AP}$ Activity}

Reed et al. $(62,71,102)$ and Sakata et al. (103) reported the use of monoclonal antibodies to inhibit human $\alpha 2 \mathrm{AP}$ activity to enhance thrombus dissolution. Mouse monoclonal antibodies caused spontaneous or $\mathrm{r}$-tPA-mediated human clot dissolution $(33,62,102,103)$. A mouse monoclonal antibody inhibitor of $\alpha 2 \mathrm{AP}$ synergistically increased fibrinolysis by $\mathrm{r}$ tPA and other types of plasminogen activators increasing the potency of these agents by 20-80-fold (62). Despite increases in fibrinolysis, equipotent combinations of $\alpha 2 \mathrm{AP}-\mathrm{I}$ with very low dose plasminogen activators caused less fibrinogen breakdown than the plasminogen activator alone. As noted earlier, $\alpha 2 \mathrm{AP}-$ I has been shown to enhance fibrinolysis in several different animal models of venous thrombosis, pulmonary embolism and ischemic stroke $(28,44,55,56,59,60,62,64,71)$. More recently, in a humanized model of pulmonary embolism in mice, an $\alpha 2 \mathrm{AP}-$ I (TS23, a monoclonal antibody that inactivates human $\alpha 2 \mathrm{AP}$ ), enhanced the dissolution of pulmonary emboli with a potency similar to higher dose r-tPA $(3 \mathrm{mg} / \mathrm{kg})$, though unlike r-tPA, this $\alpha 2$ AP-I did not increase arterial or venous bleeding (28). The $\alpha 2 \mathrm{AP}-\mathrm{I}$, TS23 prevented thrombus formation during venous stasis in mice (64). This $\alpha 2 \mathrm{AP}-\mathrm{I}$ has been tested in Phase I trials in humans (NCT03001544) and Phase II trials are planned.

\section{Microplasmin/Plasmin}

Microplasmin is a truncated version of plasmin that contains only the catalytic domain (104). Microplasmin is a non-specific enzyme that is inhibited by $\alpha 2$-macroglobulin and by $\alpha 2 \mathrm{AP}$. Infusions of microplasmin will induce secondary depletion of a2AP, which were thought to be important for its function. A single bolus of plasmin/microplasmin in mice significantly reduced focal ischemic injury in mice (58). Microplasmin also reduced ischemic brain injury and neurological function in a rat middle cerebral artery thrombosis model (105) and improved behavioral outcomes in an embolic stroke model in rabbit (106). A Phase 1 trial in humans showed that $\alpha 2 \mathrm{AP}$ inhibition by microplasmin induced a dose $(0.1-5 \mathrm{mg} / \mathrm{kg})$ related inhibition effect on $\alpha 2 \mathrm{AP}$ activity in healthy volunteers (107). In a doubleblind randomized phase II trial in stroke patients, $1-4 \mathrm{mg} / \mathrm{kg}$ 
microplasmin neutralized blood $\alpha 2 \mathrm{AP}$ by up to $80 \%$ and was well-tolerated, however, no effect on reperfusion or clinic outcome was observed possibly due to the small sample size (108). The development of microplasmin as a cardiovascular therapeutic was discontinued and, is used now for the clinical treatment of human retinal disease (109).

Infusion of plasmin will also deplete $\alpha 2 \mathrm{AP}$ and this was used as an experimental treatment for thrombotic injury in mice (58). Marder et al. (110) used a similar strategy with a different hypothesis namely, that catheter-directed localized delivery of plasmin will increase the thrombus dissolution and then the released plasmin will be neutralized by $\alpha 2 \mathrm{AP}$ in circulation so that plasmin will not have any side effects (111). Plasmin (4 mg/kg) dissolved thrombi in abdominal aorta thrombosis and did not increase bleeding (112). Plasmin of up to a dose of $8 \mathrm{mg} / \mathrm{kg}$ completely neutralized $60 \%$ of $\alpha 2 \mathrm{AP}$ activity but also caused fibrinogen, factor VIII depletion, as well as increased bleeding (113). Safety trials for plasmin in patients with acute lower extremity arterial or bypass graft occlusion showed enhanced thrombus dissolution with bleeding events in $<20 \%(114)$. Phase I/II of human plasmin in acute ischemic stroke patients showed that human plasmin was tolerable for plasmin dose up to $80 \mathrm{mg}$ within $9 \mathrm{~h}$ of stroke, but recanalization was achieved in a limited number of patients (25\%) (115). There have been no new reports of clinical development of plasmin.

\section{Inhibitors of APCE}

APCE is a $97 \mathrm{kDa}$, prolyl-specific protease in plasma that cleaves $\mathrm{Met}^{1}-\alpha 2 \mathrm{AP}$ at $\mathrm{Pro}^{12}-\mathrm{Asn}^{13}$ to generate $\mathrm{Asn}^{13}-\alpha 2 \mathrm{AP}$, which is cross-linked to fibrin 13 times faster than $\mathrm{Met}^{1}-\alpha 2 \mathrm{AP}$ (36). APCE shares a strong amino acid sequence homology to fibroblast activation protein, an integral transmembrane protein and may represent its soluble isoform or a derivative (36). It was proposed that the specific inhibitors of APCE can reduce the amount of $\alpha 2 \mathrm{AP}$ crosslinking to fibrin and thus enhance fibrinolysis. Chemically modified peptide inhibitors of APCE increased fibrinolysis in plasma clot lysis assays $(116,117)$.

\section{$\alpha 2 A P$ Mimicking Peptides}

Synthetic peptide mimicking $\alpha 2 \mathrm{AP}$ regions have been tested as a competitive inhibitor of $\alpha 2 \mathrm{AP}$ to interfere in factor XIIImediated cross-linking, plasminogen binding and activation to achieve enhanced fibrinolysis or clot lysis in vitro (118-121). The effects of these peptides or inhibitors have been studied during clot formation, but not on preformed plasma clots or in vivo thrombi in experimental models.

\section{SUMMARY}

Several different approaches have been taken to investigate the therapeutic potential of interfering with $\alpha 2 \mathrm{AP}$ function to

\section{REFERENCES}

1. Wiman B, Collen D. On the kinetics of the reaction between human antiplasmin and plasmin. Eur J Biochem. (1978) 84:573-8. doi: 10.1111/j.1432-1033.1978.tb12200.x prevent thrombosis and dissolve existing thrombi. Systemic use of microplasmin has been limited by off-target effects and its use is currently limited to the treatment of retinal disease. Plasmin administration required catheter delivery by expert teams and only achieved limited thrombotic dissolution and recanalization in ischemic stroke. The development of $\alpha 2 \mathrm{AP}$ mimicking peptides and APCE inhibitors appears uncertain as there are no reports of clinical trials. Monoclonal antibody approaches have been extensively evaluated in experimental models; they have shown high specificity, potency and the fewest off-target effects and are in development for Phase II trials in thrombotic diseases.

\section{CONCLUDING REMARKS AND FUTURE PERSPECTIVES}

Since its original description by three different laboratories in 1976, our understanding of $\alpha 2 \mathrm{AP}$ and its role in cardiovascular has evolved significantly. Epidemiologic and observational studies suggest that $\alpha 2 \mathrm{AP}$ contributes significantly to the risk of thrombotic events in cardiovascular and cerebrovascular diseases. Numerous in vitro and in vivo studies, including studies in genetically-deficient mice and humans indicate that $\alpha 2 \mathrm{AP}$ regulates endogenous and pharmacologic fibrinolysis. In addition, $\alpha 2 \mathrm{AP}$ has been implicated in experimental models of wound healing, fibrosis, neuronal function, liver repair, and Alzheimer's disease. Disease-relevant models of thrombosis have shown that blocking $\alpha 2 \mathrm{AP}$ function significantly enhances thrombus dissolution and improves outcomes, without causing bleeding. Taken together, these data suggest that therapeutically targeting $\alpha 2 \mathrm{AP}$ has promise for both treatment and prevention of acute thrombotic cardiovascular and cerebrovascular diseases.

\section{DATA AVAILABILITY STATEMENT}

The original contributions presented in the study are included in the article/supplementary material, further inquiries can be directed to the corresponding author/s.

\section{AUTHOR CONTRIBUTIONS}

SSa edited the manuscript. SSi and GR wrote, edited, and approved the manuscript. All authors contributed to the article and approved the submitted version.

\section{FUNDING}

This work was funded in part by NIH (NS089707, NS073147, and HL092750 to GR).

2. Wiman B, Collen D. On the mechanism of the reaction between human alpha 2-antiplasmin and plasmin. J Biol Chem. (1979) 254:9291-7.

3. Collen D, Wiman B. Fast-acting plasmin inhibitor in human plasma. Blood. (1978) 51:563-9. doi: 10.1182/blood.V51.4.563.563 
4. Collen D. Identification and some properties of a new fast-reacting plasmin inhibitor in human plasma. Eur J Biochem. (1976) 69:209-16. doi: 10.1111/j.1432-1033.1976.tb10875.x

5. Moroi M, Aoki N. Isolation and characterization of alpha2-plasmin inhibitor from human plasma. A novel proteinase inhibitor which inhibits activatorinduced clot lysis. J Biol Chem. (1976) 251:5956-65.

6. Mullertz S, Clemmensen I. The primary inhibitor of plasmin in human plasma. Biochem J. (1976) 159:545-53. doi: 10.1042/bj1 590545

7. Aoki N. Discovery of alpha2-plasmin inhibitor and its congenital deficiency. J Thromb Haemost. (2005) 3:623-31. doi: 10.1111/j.1538-7836.2004. 01055.x

8. Cederholm-Williams SA. Concentration of plasminogen and antiplasmin in plasma and serum. J Clin Pathol. (1981) 34:979-81. doi: 10.1136/jcp. 34.9.979

9. Roy A, Kucukural A, Zhang Y. I-TASSER: a unified platform for automated protein structure and function prediction. Nat Protoc. (2010) 5:725-38. doi: $10.1038 /$ nprot.2010.5

10. Law RH, Sofian T, Kan WT, Horvath AJ, Hitchen CR, Langendorf $\mathrm{CG}$, et al. X-ray crystal structure of the fibrinolysis inhibitor alpha2antiplasmin. Blood. (2008) 111:2049-52. doi: 10.1182/blood-2007-09114215

11. Holmes WE, Nelles L, Lijnen HR, Collen D. Primary structure of human alpha 2-antiplasmin, a serine protease inhibitor (serpin). J Biol Chem. (1987) 262:1659-64.

12. Bangert K, Johnsen AH, Christensen U, Thorsen S. Different N-terminal forms of alpha 2-plasmin inhibitor in human plasma. Biochem J. (1993) 291(Pt 2):623-5. doi: 10.1042/bj2910623

13. Lu BG, Sofian T, Law RH, Coughlin PB, Horvath AJ. Contribution of conserved lysine residues in the alpha2-antiplasmin $\mathrm{C}$ terminus to plasmin binding and inhibition. J Biol Chem. (2011) 286:24544-52. doi: 10.1074/jbc.M111.229013

14. Moroi M, Aoki N. On the interaction of alpha2-plasmin inhibitor and proteases. Evidence for the formation of a covalent crosslinkage and noncovalent weak bondings between the inhibitor and proteases. Biochim Biophys Acta. (1977) 482:412-20. doi: 10.1016/0005-2744(77)90255-8

15. Sazonova IY, Thomas BM, Gladysheva IP, Houng AK, Reed GL. Fibrinolysis is amplified by converting alpha-antiplasmin from a plasmin inhibitor to a substrate. J Thromb Haemost. (2007) 5:2087-94. doi: 10.1111/j.1538-7836.2007.02652.x

16. Hogstorp H, Saldeen T. Synthesis of alpha 2-antiplasmin by rat liver cells. Thromb Res. (1982) 28:19-25. doi: 10.1016/0049-3848(82) 90029-9

17. Fair DS, Plow EF. Synthesis and secretion of the fibrinolytic components, including alpha 2-antiplasmin, by a human hepatoma cell line. J Lab Clin Med. (1983) 101:372-84.

18. Abdul S, Leebeek FW, Rijken DC, Uitte de Willige S. Natural heterogeneity of alpha2-antiplasmin: functional and clinical consequences. Blood. (2016) 127:538-45. doi: 10.1182/blood-2015-09-670117

19. Menoud PA, Sappino N, Boudal-Khoshbeen M, Vassalli JD, Sappino AP. The kidney is a major site of alpha(2)-antiplasmin production. J Clin Invest. (1996) 97:2478-84. doi: 10.1172/JCI118694

20. Barker R, Kehoe PG, Love S. Activators and inhibitors of the plasminogen system in Alzheimer's disease. J Cell Mol Med. (2012) 16:865-76. doi: 10.1111/j.1582-4934.2011.01394.x

21. Uhlen M, Fagerberg L, Hallstrom BM, Lindskog C, Oksvold P, Mardinoglu A, et al. Proteomics: tissue-based map of the human proteome. Science. (2015) 347:1260419. doi: 10.1126/science.1260419

22. Okada K, Lijnen HR, Dewerchin M, Belayew A, Matsuo O, Collen D, et al. Characterization and targeting of the murine alpha2-antiplasmin gene. Thromb Haemost. (1997) 78:1104-10. doi: 10.1055/s-0038-1657694

23. Thomas AR, Naude RJ, Oelofsen W, Naganuma T, Muramoto K. Purification and partial characterisation of alpha(2)-antiplasmin and plasmin(ogen) from ostrich plasma. Comp Biochem Physiol B Biochem Mol Biol. (2001) 129:80920. doi: 10.1016/S1096-4959(01)00396-7

24. Piliavskaia AS, Panchenko NE. [Alpha 2-antiplasmin in bovine plasma]. $U k r$ Biokhim Zh (1978). (1985) 57:65-7.
25. Tone M, Kikuno R, Kume-Iwaki A, Hashimoto-Gotoh T. Structure of human alpha 2-plasmin inhibitor deduced from the cDNA sequence. J Biochem. (1987) 102:1033-41. doi: 10.1093/oxfordjournals.jbchem.a122141

26. Coughlin PB. Antiplasmin. the forgotten serpin? FEBS J. (2005) 272:4852-7. doi: 10.1111/j.1742-4658.2005.04881.x

27. Lijnen HR, van Hoef B, Beelen V, Collen D. Characterization of the murine plasma fibrinolytic system. Eur J Biochem. (1994) 224:863-71. doi: 10.1111/j.1432-1033.1994.00863.x

28. Singh S, Houng A, Reed GL. Releasing the brakes on the fibrinolytic system in pulmonary emboli: unique effects of plasminogen activation and alpha2-antiplasmin inactivation. Circulation. (2017) 135:1011-20. doi: 10.1161/CIRCULATIONAHA.116.024421

29. Kluft C, Los P, Jie AF. The molecular form of alpha 2-antiplasmin with affinity for plasminogen is selectively bound to fibrin by factor XIII. Thromb Res. (1984) 33:419-25. doi: 10.1016/0049-3848(84)90081-1

30. Sakata Y, Aoki N. Cross-linking of alpha 2-plasmin inhibitor to fibrin by fibrin-stabilizing factor. J Clin Invest. (1980) 65:290-7. doi: 10.1172/JCI109671

31. Sakata Y, Aoki N. Significance of cross-linking of alpha 2-plasmin inhibitor to fibrin in inhibition of fibrinolysis and in hemostasis. J Clin Invest. (1982) 69:536-42. doi: 10.1172/JCI110479

32. Reed GL, Matsueda GR, Haber E. Fibrin-fibrin and alpha 2-antiplasminfibrin cross-linking by platelet factor XIII increases the resistance of platelet clots to fibrinolysis. Trans Assoc Am Physicians. (1991) 104:21-8.

33. Reed GL. Functional characterization of monoclonal antibody inhibitors of alpha 2-antiplasmin that accelerate fibrinolysis in different animal plasmas. Hybridoma. (1997) 16:281-6. doi: 10.1089/hyb.1997.16.281

34. Fraser SR, Booth NA, Mutch NJ. The antifibrinolytic function of factor XIII is exclusively expressed through alpha(2)-antiplasmin cross-linking. Blood. (2011) 117:6371-4. doi: 10.1182/blood-2011-02-333203

35. Rijken DC, Uitte de Willige S. Inhibition of fibrinolysis by coagulation factor XIII. Biomed Res Int. (2017) 2017:1209676. doi: 10.1155/2017/1209676

36. Lee KN, Jackson KW, Christiansen VJ, Chung KH, McKee PA. A novel plasma proteinase potentiates alpha2-antiplasmin inhibition of fibrin digestion. Blood. (2004) 103:3783-8. doi: 10.1182/blood-2003-12-4240

37. Wiman B, Lijnen HR, Collen D. On the specific interaction between the lysine-binding sites in plasmin and complementary sites in alpha2antiplasmin and in fibrinogen. Biochim Biophys Acta. (1979) 579:142-54. doi: 10.1016/0005-2795(79)90094-1

38. Lee AY, Fredenburgh JC, Stewart RJ, Rischke JA, Weitz JI. Like fibrin, (DD)E, the major degradation product of crosslinked fibrin, protects plasmin from inhibition by alpha2-antiplasmin. Thromb Haemost. (2001) 85:502-8. doi: 10.1055/s-0037-1615612

39. Rouy D, Angles-Cano E. The mechanism of activation of plasminogen at the fibrin surface by tissue-type plasminogen activator in a plasma milieu in vitro. Role of alpha 2-antiplasmin. Biochem J. (1990) 271:51-7. doi: 10.1042/bj2710051

40. Hall SW, Humphries JE, Gonias SL. Inhibition of cell surface receptor-bound plasmin by alpha 2-antiplasmin and alpha 2-macroglobulin. J Biol Chem. (1991) 266:12329-36.

41. Ariens RA, Lai TS, Weisel JW, Greenberg CS, Grant PJ. Role of factor XIII in fibrin clot formation and effects of genetic polymorphisms. Blood. (2002) 100:743-54. doi: 10.1182/blood.V100.3.743

42. Hethershaw EL, Cilia La Corte AL, Duval C, Ali M, Grant PJ, Ariëns RA, et al. The effect of blood coagulation factor XIII on fibrin clot structure and fibrinolysis. J Thromb Haemost. (2014) 12:197-205. doi: 10.1111/jth. 12455

43. Rijken DC, Abdul S, Malfliet JJ, Leebeek FW, Uitte de Willige $\mathrm{S}$. Compaction of fibrin clots reveals the antifibrinolytic effect of factor XIII. J Thromb Haemost. (2016) 14:1453-61. doi: 10.1111/jth. 13354

44. Reed GL, Houng AK. The contribution of activated factor XIII to fibrinolytic resistance in experimental pulmonary embolism. Circulation. (1999) 99:299304. doi: 10.1161/01.CIR.99.2.299

45. Aleman MM, Byrnes JR, Wang JG, Tran R, Lam WA, Di Paola J, et al. Factor XIII activity mediates red blood cell retention in venous thrombi. J Clin Invest. (2014) 124:3590-600. doi: 10.1172/JCI75386 
46. Byrnes JR, Duval C, Wang Y, Hansen CE, Ahn B, Mooberry MJ, et al. Factor XIIIa-dependent retention of red blood cells in clots is mediated by fibrin alpha-chain crosslinking. Blood. (2015) 126:1940-8. doi: 10.1182/blood-2015-06-652263

47. Mutch NJ, Thomas L, Moore NR, Lisiak KM, Booth NTAFIa A, PAI-1 and alpha-antiplasmin. complementary roles in regulating lysis of thrombi and plasma clots. J Thromb Haemost. (2007) 5:812-7. doi: 10.1111/j.1538-7836.2007.02430.x

48. Nagashima M, Yin ZF, Broze GJ Jr, Morser J. Thrombin-activatable fibrinolysis inhibitor (TAFI) deficient mice. Front Biosci. (2002) 7:d556-68. doi: 10.2741/A794

49. Vercauteren E, Peeters M, Hoylaerts MF, Lijnen HR, Meijers JC, Declerck PJ, et al. The hyperfibrinolytic state of mice with combined thrombin-activatable fibrinolysis inhibitor (TAFI) and plasminogen activator inhibitor-1 gene deficiency is critically dependent on TAFI deficiency. J Thromb Haemost. (2012) 10:2555-62. doi: 10.1111/jth.12036

50. Dewerchin M, Collen D, Lijnen HR. Enhanced fibrinolytic potential in mice with combined homozygous deficiency of alpha2-antiplasmin and PAI-1. Thromb Haemost. (2001) 86:640-6. doi: 10.1055/s-0037-1616099

51. Campbell BCV, De Silva DA, Macleod MR, Coutts SB, Schwamm LH, Davis SM, et al. Ischaemic stroke. Nat Rev Dis Primers. (2019) 5:70. doi: 10.1038/s41572-019-0118-8

52. Suri MF, Yamagishi K, Aleksic N, Hannan PJ, Folsom AR. Novel hemostatic factor levels and risk of ischemic stroke: the Atherosclerosis Risk in Communities (ARIC) Study. Cerebrovasc Dis. (2010) 29:497-502. doi: 10.1159/000297966

53. Marti-Fabregas J, Borrell M, Cocho D, Belvis $R$, Castellanos $M$, Montaner J, et al. Hemostatic markers of recanalization in patients with ischemic stroke treated with rt-PA. Neurology. (2005) 65:366-70. doi: 10.1212/01.wnl.0000171704.50395.ba

54. Reed GL, Houng AK, Singh S, Wang D. alpha2-antiplasmin: new insights and opportunities for ischemic stroke. Semin Thromb Hemost. (2017) 43:191-9. doi: 10.1055/s-0036-1585077

55. Houng AK, Wang D, Reed GL. Reversing the deleterious effects of alpha2-antiplasmin on tissue plasminogen activator therapy improves outcomes in experimental ischemic stroke. Exp Neurol. (2014) 255:56-62. doi: 10.1016/j.expneurol.2014.02.009

56. Reed GL, Houng AK, Wang D. Microvascular thrombosis, fibrinolysis, ischemic injury, and death after cerebral thromboembolism are affected by levels of circulating alpha2-antiplasmin. Arterioscler Thromb Vasc Biol. (2014) 34:2586-93. doi: 10.1161/ATVBAHA.114.304530

57. Nagai N, De Mol M, Lijnen HR, Carmeliet P, Collen D. Role of plasminogen system components in focal cerebral ischemic infarction: a gene targeting and gene transfer study in mice. Circulation. (1999) 99:2440-4. doi: 10.1161/01.CIR.99.18.2440

58. Nagai N, De Mol M, Van Hoef B, Verstreken M, Collen D. Depletion of circulating alpha(2)-antiplasmin by intravenous plasmin or immunoneutralization reduces focal cerebral ischemic injury in the absence of arterial recanalization. Blood. (2001) 97:3086-92. doi: 10.1182/blood.V97.10.3086

59. Su EJ, Lawrence DA. alpha2 Antiplasmin and microvascular thrombosis in ischemic stroke. Arterioscler Thromb Vasc Biol. (2014) 34:2522-3. doi: 10.1161/ATVBAHA.114.304616

60. Butte AN, Houng AK, Jang IK, Reed GL. Alpha 2-antiplasmin causes thrombi to resist fibrinolysis induced by tissue plasminogen activator in experimental pulmonary embolism. Circulation. (1997) 95:1886-91. doi: 10.1161/01.CIR.95.7.1886

61. Lijnen HR, Okada K, Matsuo O, Collen D, Dewerchin M. Alpha2antiplasmin gene deficiency in mice is associated with enhanced fibrinolytic potential without overt bleeding. Blood. (1999) 93:2274-81. doi: 10.1182/blood.V93.7.2274

62. Reed GL III, Matsueda GR, Haber E. Synergistic fibrinolysis: combined effects of plasminogen activators and an antibody that inhibits alpha 2-antiplasmin. Proc Natl Acad Sci U S A. (1990) 87:1114-8. doi: 10.1073/pnas.87.3.1114

63. Matsuno H, Kozawa O, Okada K, Ueshima S, Matsuo O, Uematsu T. Plasmin generation plays different roles in the formation and removal of arterial and venous thrombus in mice. Thromb Haemost. (2002) 87:98-104. doi: 10.1055/s-0037-1612950

64. Singh S, Houng A, Reed G. Venous stasis-induced fibrinolysis prevents thrombosis in mice: role of alpha2-antiplasmin. Blood. (2019) 134:970-8. doi: 10.1182/blood.2019000049

65. Matsuno H, Ishisaki A, Nakajima K, Okada K, Ueshima S, Matsuo O, et al. Lack of alpha: 2-antiplasmin promotes re-endothelialization via overrelease of VEGF after vascular injury in mice. Blood. (2003) 102:3621-8. doi: 10.1182/blood-2003-03-0700

66. Matsuno H, Kozawa O, Yoshimi N, Akamatsu S, Hara A, Mori H, et al. Lack of alpha2-antiplasmin promotes pulmonary heart failure via overrelease of VEGF after acute myocardial infarction. Blood. (2002) 100:2487-93. doi: 10.1182/blood-2001-12-0251

67. Singh S, Houng AK, Reed GL. Matrix metalloproteinase-9 mediates the deleterious effects of alpha2-antiplasmin on blood-brain barrier breakdown and ischemic brain injury in experimental stroke. Neuroscience. (2018) 376:40-7. doi: 10.1016/j.neuroscience.2017.12.021

68. Suzuki Y, Nagai N, Collen D. Comparative effects of microplasmin and tissue-type plasminogen activator (tPA) on cerebral hemorrhage in a middle cerebral artery occlusion model in mice. J Thromb Haemost. (2004) 2:161721. doi: 10.1111/j.1538-7836.2004.00889.x

69. Chen F, Suzuki Y, Nagai N, Sun X, Wang H, Yu J, et al. Microplasmin and tissue plasminogen activator: comparison of therapeutic effects in rat stroke model at multiparametric MR imaging. Radiology. (2007) 244:429-38. doi: 10.1148/radiol.2442061316

70. Mukhopadhyay S, Johnson TA, Duru N, Buzza MS, Pawar NR, Sarkar R, et al. Fibrinolysis and inflammation in venous thrombus resolution. Front Immunol. (2019) 10:1348. doi: 10.3389/fimmu.2019.01348

71. Reed GL III, Matsueda GR, Haber E. Inhibition of clot-bound alpha 2antiplasmin enhances in vivo thrombolysis. Circulation. (1990) 82:164-8. doi: 10.1161/01.CIR.82.1.164

72. Huisman MV, Barco S, Cannegieter SC, Le Gal G, Konstantinides SV, Reitsma PH, et al. Pulmonary embolism. Nat Rev Dis Primers. (2018) 4:18028. doi: 10.1038/nrdp.2018.28

73. Matsuno H, Okada K, Ueshima S, Matsuo O, Kozawa O. Alpha2-antiplasmin plays a significant role in acute pulmonary embolism. J Thromb Haemost. (2003) 1:1734-9. doi: 10.1046/j.1538-7836.2003.00252.x

74. Lijnen HR, Van Hoef B, Dewerchin M, Collen D. Alpha(2)-antiplasmin gene deficiency in mice does not affect neointima formation after vascular injury. Arterioscler Thromb Vasc Biol. (2000) 20:1488-92. doi: 10.1161/01.ATV.20.6.1488

75. Hou Y, Okada K, Okamoto C, Ueshima S, Matsuo O. Alpha2antiplasmin is a critical regulator of angiotensin II-mediated vascular remodeling. Arterioscler Thromb Vasc Biol. (2008) 28:1257-62. doi: 10.1161/ATVBAHA.108.165688

76. Vogel B, Claessen BE, Arnold SV, Chan D, Cohen DJ, Giannitsis E, et al. STsegment elevation myocardial infarction. Nat Rev Dis Primers. (2019) 5:39. doi: 10.1038/s41572-019-0090-3

77. Tang YP, Liu Y, Fan YJ, Zhao YY, Feng JQ, Liu Y. To develop a novel animal model of myocardial infarction: a research imperative. Animal Model Exp Med. (2018) 1:36-9. doi: 10.1002/ame2.12010

78. Tsai HM. Pathophysiology of thrombotic thrombocytopenic purpura. Int J Hematol. (2010) 91:1-19. doi: 10.1007/s12185-0090476-1

79. Tersteeg C, Joly BS, Gils A, Lijnen R, Deckmyn H, Declerck PJ, et al. Amplified endogenous plasmin activity resolves acute thrombotic thrombocytopenic purpura in mice. J Thromb Haemost. (2017) 15:2432-42. doi: $10.1111 /$ jth.13859

80. Kanno Y, Kuroki A, Okada K, Tomogane K, Ueshima S, Matsuo O, et al. Alpha2-antiplasmin is involved in the production of transforming growth factor betal and fibrosis. J Thromb Haemost. (2007) 5:2266-73. doi: 10.1111/j.1538-7836.2007.02745.x

81. Kanno Y, Kawashita E, Kokado A, Okada K, Ueshima S, Matsuo O, et al. Alpha2-antiplasmin regulates the development of dermal fibrosis in mice by prostaglandin $\mathrm{F}$ (2alpha) synthesis through adipose triglyceride lipase/calcium-independent phospholipase A(2). Arthritis Rheum. (2013) 65:492-502. doi: 10.1002/art.37767 
82. Paquet-Fifield S, Roufail S, Zhang YF, Sofian T, Byrne DJ, Coughlin $\mathrm{PB}$, et al. The fibrinolysis inhibitor alpha2-antiplasmin restricts lymphatic remodelling and metastasis in a mouse model of cancer. Growth Factors. (2017) 35:61-75. doi: 10.1080/08977194.2017.1349765

83. Kawashita E, Kanno Y, Asayama H, Okada K, Ueshima S, Matsuo $\mathrm{O}$, et al. Involvement of alpha2-antiplasmin in dendritic growth of hippocampal neurons. J Neurochem. (2013) 126:58-69. doi: 10.1111/jnc. 12281

84. Kanno Y, Kawashita E, Kokado A, Kuretake H, Ikeda K, Okada K, et al. alpha2AP mediated myofibroblast formation and the development of renal fibrosis in unilateral ureteral obstruction. Sci Rep. (2014) 4:5967. doi: 10.1038/srep05967

85. Kawashita E, Kanno Y, Ikeda K, Kuretake H, Matsuo O, Matsuno H. Altered behavior in mice with deletion of the alpha2-antiplasmin gene. PLoS One. (2014) 9:e97947. doi: 10.1371/journal.pone.00 97947

86. Baker SK, Chen ZL, Norris EH, Revenko AS, MacLeod AR, Strickland S. Blood-derived plasminogen drives brain inflammation and plaque deposition in a mouse model of Alzheimer's disease. Proc Natl Acad Sci U S A. (2018) 115:E9687-E96. doi: 10.1073/pnas.1811 172115

87. Kanno Y, Hirade K, Ishisaki A, Nakajima K, Suga H, Into T, et al. Lack of alpha2-antiplasmin improves cutaneous wound healing via over-released vascular endothelial growth factor-induced angiogenesis in wound lesions. $J$ Thromb Haemost. (2006) 4:1602-10. doi: 10.1111/j.1538-7836.2006.01978.x

88. Okada K, Ueshima S, Imano M, Kataoka K, Matsuo O. The regulation of liver regeneration by the plasmin/alpha 2-antiplasmin system. J Hepatol. (2004) 40:110-6. doi: 10.1016/j.jhep.2003.09.016

89. Koie K, Kamiya T, Ogata K, Takamatsu J. Alpha2plasmin-inhibitor deficiency (Miyasato disease). Lancet. (1978) 2:1334-6. doi: 10.1016/S0140-6736(78) 91973-6

90. Aoki N, Saito H, Kamiya T, Koie K, Sakata Y, Kobakura M. Congenital deficiency of alpha 2-plasmin inhibitor associated with severe hemorrhagic tendency. J Clin Invest. (1979) 63:877-84. doi: 10.1172/JCI109387

91. Favier R, Aoki N, de Moerloose P. Congenital alpha(2)-plasmin inhibitor deficiencies. a review. Br J Haematol. (2001) 114:4-10. doi: 10.1046/j.1365-2141.2001.02845.x

92. Vigano S, D'Andrea G, Valle PD, Santacroce R, Margaglione M, D'Angelo A. A novel allele variant of the SERPINF2 gene responsible for severe plasmin inhibitor (alpha2-antiplasmin) deficiency in an Italian patient. Thromb Res. (2018) 166:60-2. doi: 10.1016/j.thromres.2018.04.006

93. Ikematsu S, Fukutake K, Aoki N. Heterozygote for plasmin inhibitor deficiency developing hemorrhagic tendency with advancing age. Thromb Res. (1996) 82:129-16. doi: 10.1016/0049-3848(96)00059-X

94. Holmes WE, Lijnen HR, Nelles L, Kluft C, Nieuwenhuis HK, Rijken DC, et al. Alpha 2-antiplasmin Enschede: alanine insertion and abolition of plasmin inhibitory activity. Science. (1987) 238:209-11. doi: 10.1126/science.2958938

95. Rijken DC, Groeneveld E, Kluft C, Nieuwenhuis HK. Alpha 2-antiplasmin Enschede is not an inhibitor, but a substrate, of plasmin. Biochem J. (1988) 255:609-15.

96. Meltzer ME, Doggen CJ, de Groot PG, Rosendaal FR, Lisman T. Plasma levels of fibrinolytic proteins and the risk of myocardial infarction in men. Blood. (2010) 116:529-36. doi: 10.1182/blood-2010-01-263103

97. Collen D, Verstraete M. alpha 2-Antiplasmin consumption and fibrinogen breakdown during thrombolytic therapy. Thromb Res. (1979) 14:631-9. doi: 10.1016/0049-3848(79)90118-X

98. Leebeek FW, Kluft C, Knot EA, Los P, Cohen AF, Six AJ. Plasmin inhibitors in the prevention of systemic effects during thrombolytic therapy: specific role of the plasminogen-binding form of alpha 2-antiplasmin. J Am Coll Cardiol. (1990) 15:1212-20. doi: 10.1016/S0735-1097(10)80003-8

99. Weitz JI, Leslie B, Hirsh J, Klement P. Alpha 2-antiplasmin supplementation inhibits tissue plasminogen activator-induced fibrinogenolysis and bleeding with little effect on thrombolysis. J Clin Invest. (1993) 91:1343-50. doi: 10.1172/JCI116335

100. Wendelboe AM, Raskob GE. Global burden of thrombosis. Epidemiologic Aspects. Circ Res. (2016) 118:1340-7. doi: 10.1161/CIRCRESAHA.115.306841
101. Wolberg AS, Rosendaal FR, Weitz JI, Jaffer IH, Agnelli G, Baglin T, et al. Venous thrombosis. Nat Rev Dis Primers. (2015) 1:15006. doi: $10.1038 / \mathrm{nrdp} .2015 .6$

102. Reed GL III, Matsueda GR, Haber E. Acceleration of plasma clot lysis by an antibody to alpha 2-antiplasmin. Trans Assoc Am Physicians. (1988) 101:250-6.

103. Sakata Y, Eguchi Y, Mimuro J, Matsuda M, Sumi Y. Clot lysis induced by a monoclonal antibody against alpha 2-plasmin inhibitor. Blood. (1989) 74:2692-7. doi: 10.1182/blood.V74.8.269 2.2692

104. Nagai N, Demarsin E, Van Hoef B, Wouters S, Cingolani D, Laroche $\mathrm{Y}$, et al. Recombinant human microplasmin: production and potential therapeutic properties. J Thromb Haemost. (2003) 1:307-13. doi: 10.1046/j.1538-7836.2003.00078.x

105. Suzuki Y, Chen F, Ni Y, Marchal G, Collen D, Nagai N. Microplasmin reduces ischemic brain damage and improves neurological function in a rat stroke model monitored with MRI. Stroke. (2004) 35:2402-6. doi: 10.1161/01.STR.0000140628.00927.1a

106. Lapchak PA, Araujo DM, Pakola S, Song D, Wei J, Zivin JA. Microplasmin: a novel thrombolytic that improves behavioral outcome after embolic strokes in rabbits. Stroke. (2002) 33:2279-84. doi: 10.1161/01.STR.0000028267.09604.7B

107. Pakola S, Cahillane G, Stassen JM, Lijnen HR, Verhamme P. Neutralization of alpha(2)-antiplasmin by microplasmin: a randomized, doubleblind, placebo-controlled, ascending-dose study in healthy male volunteers. Clin Ther. (2009) 31:1688-706. doi: 10.1016/j.clinthera.2009. 08.019

108. Thijs VN, Peeters A, Vosko M, Aichner F, Schellinger PD, Schneider D, et al. Randomized, placebo-controlled, dose-ranging clinical trial of intravenous microplasmin in patients with acute ischemic stroke. Stroke. (2009) 40:378995. doi: 10.1161/STROKEAHA.109.560201

109. Syed YY, Dhillon S. Ocriplasmin: a review of its use in patients with symptomatic vitreomacular adhesion. Drugs. (2013) 73:1617-25. doi: 10.1007/s40265-013-0124-1

110. Marder VJ, Novokhatny V. Direct fibrinolytic agents: biochemical attributes, preclinical foundation and clinical potential. J Thromb Haemost. (2010) 8:433-44. doi: 10.1111/j.1538-7836.2009.03701.x

111. Novokhatny VV, Jesmok GJ, Landskroner KA, Marder VJ, Zimmerman TP. Locally delivered plasmin: why should it be superior to plasminogen activators for direct thrombolysis? Trends Pharmacol Sci. (2004) 25:72-5. doi: 10.1016/j.tips.2003.12.009

112. Marder VJ, Landskroner K, Novokhatny V, Zimmerman TP, Kong M, Kanouse JJ, et al. Plasmin induces local thrombolysis without causing hemorrhage: a comparison with tissue plasminogen activator in the rabbit. Thromb Haemost. (2001) 86:739-45. doi: 10.1055/s-0037-1 616127

113. Stewart D, Kong M, Novokhatny V, Jesmok G, Marder VJ. Distinct dose-dependent effects of plasmin and TPA on coagulation and hemorrhage. Blood. (2003) 101:3002-7. doi: 10.1182/blood-200208-2546

114. Marder VJ, Comerota AJ, Shlansky-Goldberg RD, Davis JP, Deng C, Hanna K, et al. Safety of catheter-delivered plasmin in patients with acute lower extremity arterial or bypass graft occlusion. phase I results. J Thromb Haemost. (2012) 10:985-91. doi: 10.1111/j.1538-7836.2012. 04728.x

115. Mitchell PJ, Yan B, Brozman M, Ribo M, Marder V, Courtney KL, et al. Plasmin (human) administration in acute middle cerebral artery ischemic stroke. Phase 1/2a, open-label, dose-escalation, safety study. J Stroke Cerebrovasc Dis. (2017) 26:308-20. doi: 10.1016/j.jstrokecerebrovasdis.2016. 09.022

116. Lee KN, Jackson KW, Terzyan S, Christiansen VJ, McKee PA. Using substrate specificity of antiplasmin-cleaving enzyme for fibroblast activation protein inhibitor design. Biochemistry. (2009) 48:5149-58. doi: 10.1021/bi9 $00257 \mathrm{~m}$

117. Lee KN, Jackson KW, Christiansen VJ, Dolence EK, McKee PA. Enhancement of fibrinolysis by inhibiting enzymatic cleavage of precursor alpha2-antiplasmin. J Thromb Haemost. (2011) 9:987-96. doi: 10.1111/j.1538-7836.2011.04195.x 
118. Ichinose A, Tamaki T, Aoki N. Factor XIII-mediated cross-linking of NH2terminal peptide of alpha 2-plasmin inhibitor to fibrin. FEBS Lett. (1983) 153:369-71. doi: 10.1016/0014-5793(83)80645-0

119. Kimura S, Tamaki T, Aoki N. Acceleration of fibrinolysis by the Nterminal peptide of alpha 2-plasmin inhibitor. Blood. (1985) 66:157-60. doi: 10.1182/blood.V66.1.157.157

120. Lee KN, Jackson KW, McKee PA. Effect of a synthetic carboxy-terminal peptide of alpha(2)-antiplasmin on urokinase-induced fibrinolysis. Thromb Res. (2002) 105:263-70. doi: 10.1016/S0049-3848(02)00030-0

121. Sheffield WP, Eltringham-Smith LJ, Gataiance S, Bhakta V. Addition of a sequence from alpha2-antiplasmin transforms human serum albumin into a blood clot component that speeds clot lysis. BMC Biotechnol. (2009) 9:15. doi: $10.1186 / 1472-6750-9-15$
Conflict of Interest: GR is the founder of Translational Sciences.

The remaining authors declare that the research was conducted in the absence of any commercial or financial relationships that could be construed as a potential conflict of interest.

Copyright ( 12020 Singh, Saleem and Reed. This is an open-access article distributed under the terms of the Creative Commons Attribution License (CC BY). The use, distribution or reproduction in other forums is permitted, provided the original author(s) and the copyright owner(s) are credited and that the original publication in this journal is cited, in accordance with accepted academic practice. No use, distribution or reproduction is permitted which does not comply with these terms. 